А. І. Федосов, В. С. Кисличенко, О. М. Новосел

НАЦІОНАЛЬНИЙ ФАРМАЦЕВТИЧНИЙ УНІВЕРСИТЕТ, ХАРКІВ

\title{
ВИЗНАЧЕННЯ КІЛЬКІСНОГО ВМІСТУ СУМИ ФЕНОЛЬНИХ СПОЛУК В АРТИШОКУ СУЦВІТТЯХ, ЧАСНИКУ ЛИСТІ ТА ЦИБУЛИНАХ
}

Вступ. Фенольні сполуки - найбільш поширений клас біологічно активних речовин рослинного походження. Вони проявляють антиоксидантну, протипухлинну, антимутагенну, антиатеросклеротичну, антибактеріальну, противірусну, седативну, противиразкову і протизапальну дію. Значне розповсюдження френольних сполук у рослинному світі та їх застосування в медичній практиці зумовлюють актуальність визначення їх кількісного вмісту в перспективних видах рослин, таких, як артишок посівний і часник посівний.

Мета дослідження - визначити кількісний вміст суми френольних сполук в артишоку суцвіттях, часнику листі та цибулинах.

Методи дослідження. Об'єктами дослідження було обрано артишоку суцвіття, часнику листя та цибулини. Кількісний вміст суми френольних сполук у них визначали, використовуючи різні методи: перманганатометричний, спектрофротометричний у перерахунку на галову кислоту, спектрофотометричний за методикою ДФу.

Результати й обговорення. Кількісний вміст суми френольних сполук, визначений перманганатометричним методом, в артишоку суцвіттях становив 9,74 \%, у часнику листі - 8,96 \%, у часнику цибулинах 4,85 \%; вміст, визначений спектрофотометричним методом у перерахунку на галову кислоту, в артишоку суцвіттях складав 6,58 \%, у часнику листі - 6,22 \%, у часнику цибулинах - 2,87 \%; вміст, визначений спектрофотометричним методом за методикою ДФу, в артишоку суцвіттях становив 4,43 \%, у часнику листі - 3,91\%, у часнику цибулинах - 2,11\%.

Висновки. Кількісний вміст суми оренольних сполук в артишоку суцвіттях, часнику листі та цибулинах визначали різними методами: перманганатометричним, спектрофометричним у перерахунку на галову кислоту, спектрофометричним за методикою ДФу. У результаті проведеного експерименту було встановлено, що френольні сполуки більше накопичуються в артишоку суцвіттях і часнику листі, а в часнику цибулинах їх вміст нижчий. Одержані результати дозволяють рекомендувати артишоку суцвіття, часнику листя та цибулини як рослинні джерела френольних сполук у складі лікарських субстанцій.

КЛЮЧОВІ СЛОВА: артишок посівний; часник посівний; фенольні сполуки; перманганатометрія; спектрофотометрія; кількісне визначення.

ВСТУП. Фенольні сполуки - найбільш поширений клас біологічно активних речовин рослинного походження [1]. Фенольні сполуки рослинного походження здатні нейтралізувати вільні радикали, активні форми оксигену і продукти їх взаємодії з органічними молекулами, а також проявляти антимутагенну активність [2]. Їм притаманна антиоксидантна, протипухлинна, антимутагенна, антиатеросклеротична, антибактеріальна, противірусна, седативна, противиразкова і протизапальна дія. Вони підвищують міцність капілярів, послаблюють дію щитоподібної залози при її гіперфуункції, є природними синергістами аскорбінової кислоти [3]. Окремі френольні (с А. І. Федосов, В. С. Кисличенко, О. М. Новосел, 2018. сполуки здатні впливати на вміст цукру в крові, ритміку серцевого м'яза, брати участь у регуляції діяльності фоункцій мозку, легень, печінки і нирок [4]. Відомо, що поліфеноли підтримують кисневу забезпеченість тканин на оптимальному рівні та запобігають негативному впливу факторів зовнішнього середовища [5].

Значне розповсюдження фенольних сполук у рослинному світі та їх застосування в медичній практиці зумовлюють актуальність визначення їх кількісного вмісту в перспективних видах рослин, таких, як артишок посівний і часник посівний.

Мета дослідження - визначити кількісний вміст суми френольних сполук в артишоку суцвіттях, часнику листі та цибулинах. 
МЕТОДИ ДОСЛІДЖЕННЯ. Об'єктами дослідження було обрано артишоку суцвіття, часнику листя та цибулини.

Кількісний вміст суми феенольних сполук в об'єктах, які досліджували, визначали різними методами.

Перманганатометричне титрування. Близько 2,0 г (точна наважка) подрібненої сировини, просіяної крізь сито з діаметром отворів 3 мм, поміщали в конічну колбу місткістю 500 мл, заливали 250 мл нагрітої до кипіння води та кип'ятили зі зворотним холодильником на електричній плитці із закритою спіраллю протягом 30 хв при періодичному перемішуванні. Рідину охолоджували до кімнатної температури та проціджували близько 100 мл у конічну колбу місткістю 200-250 мл крізь вату так, щоб частки сировини не потрапили в колбу.

Відбирали піпеткою 25 мл одержаної витяжки в іншу конічну колбу місткістю 750 мл, додавали 500 мл води, 25 мл розчину індигосульфокислоти та титрували при постійному перемішуванні розчином калію перманганату (0,02 моль/л) до золотисто-жовтого забарвлення.

Паралельно проводили контрольний дослід.

1 мл розчину калію перманганату (0,02 моль/л) відповідає 0,00582 г дубильних речовин у перерахунку на танін.

Вміст суми окиснюваних поліфенолів $(X, \%)$ у перерахунку на абсолютно суху сировину розраховували за фрормулою:

$$
X=\frac{\left(V-V_{1}\right) \cdot 0,00582 \cdot 250 \cdot 100 \cdot 100}{m \cdot 25 \cdot(100-W)},
$$

де $V$ - об'єм розчину калію перманганату $(0,02$ моль/л), який витрачено на титрування витяжки, мл;

$V_{1}$ - об'єм розчину калію перманганату $(0,02$ моль/л), який витрачено на титрування в контрольному досліді, мл;

0,00582 - кількість дубильних речовин, що відповідає 1 мл розчину калію перманганату (0,02 моль/л) (у перерахунку на танін), г;

$m$ - маса сировини, г;

W - втрата в масі при висушуванні сировини, \%;

250 - загальний об'єм витяжки, мл;

25 - об'єм витяжки, взятий для титрування, мл [6].

Спектрофотометричне визначення в перерахунку на галову кислоту. Близько 3,0 г (точна наважка) сировини поміщали в конічну колбу місткістю 100 мл з притертою пробкою, заливали 50 мл 70 \% етанолу, закривали пробкою та зважували (похибка - 0,01 г). Колбу з'єднували зі зворотним холодильником, нагрівали на водяній бані при температурі $50-60{ }^{\circ} \mathrm{C}$ протягом 2-3 год. Після цього колбу охолоджували, закривали пробкою, зважували, доводили до початкової маси 70 \% етанолом і вміст фрільтрували крізь сухий паперовий фрільтр у суху колбу місткістю 50 мл. Відбирали 10,0 мл фрільтрату, переносили в мірну колбу місткістю 50 мл і доводили 70 \% етанолом до позначки. Оптичну густину вимірювали на спектрофотометрі Месаsys Optizen POР за довжини хвилі 270 нм у кюветі $з$ товщиною шару 10 мм. Розчином порівняння був $70 \%$ етанол.

Паралельно вимірювали оптичну густину розчину фрармакопейного стандартного зразка галової кислоти.

Вміст суми сренольних сполук $(X, \%)$ у перерахунку на галову кислоту й абсолютно суху сировину обчислювали за фрормулою:

$$
X=\frac{A \cdot m_{0} \cdot K \cdot 50 \cdot 0,25 \cdot 100}{A_{0} \cdot m \cdot 25 \cdot 25},
$$

чину;

де $A$ - оптична густина досліджуваного роз-

$A_{0}$ - оптична густина стандартного розчину (галової кислоти);

$m_{0}$ - маса наважки стандартного розчину, г;

$m$ - маса наважки сировини, г;

$K$ - коесріцієнт розведення $[7,8]$.

Спектрооротометричне визначення за методикою ДФУ. 1,000 г здрібненої на порошок сировини (180) (2.9.12) поміщали в круглодонну колбу місткістю 250 мл, додавали 150 мл води $P$. Нагрівали протягом 30 хв на водяній бані, охолоджували під проточною водою та кількісно переносили в мірну колбу місткістю 250 мл. Круглодонну колбу обполіскували водою $P$, промивні води переносили в мірну колбу і доводили об'єм розчину водою $P$ до 250,0 мл. Давали осаду осісти та рідину фрільтрували крізь фільтрувальний папір діаметром 125 мм. Відкидали перші 50 мл фрільтрату.

Сумаполісренолів. 5,0 мл фрільтрату доводили водою $P$ до 25,0 мл. Суміш 2,0 мл одержаного розчину, 1,0 мл сроссрорно-молібденово-вольфррамового реактиву $P$ і 10,0 мл води $P$ доводили розчином 290 г/л натрію карбонату $P$ до об'єму 25,0 мл. Через 30 хв вимірювали оптичну густину (2.2.25) розчину за довжини хвилі 760 нм $\left(\mathrm{A}_{1}\right)$, використовуючи як компенсаційний розчин воду $P$.

Полісреноли, що не адсорбуються шкірним порошком. До 10,0 мл фрільтрату додавали 0,10 г фармакопейного стандартного зразка шкірного порошку й енергійно струшували протягом 60 хв. Суміш фрільтрували і доводили 5,0 мл фрільтрату водою Р до об'єму 25,0 мл.

Суміш 2,0 мл одержаного розчину, 1,0 мл фоосфорно-молібденово-вольфррамового реактиву $P$ і 10,0 мл води $P$ доводили розчином 290 г/л натрію карбонату $P$ до об'єму 25,0 мл. 
Через 30 хв вимірювали оптичну густину (2.2.25) розчину за довжини хвилі 760 нм $\left(\mathrm{A}_{2}\right)$, використовуючи як компенсаційний розчин воду $P$.

Стандартний розчин. Безпосередньо перед випробуванням 50,0 мг пірогалолу $P$ розчиняли у воді $P$ і доводили об'єм розчину тим самим розчинником до 100,0 мл. 5,0 мл одержаного розчину доводили водою $P$ до об'єму 100,0 мл.

Суміш 2,0 мл одержаного розчину, 1,0 мл фоссрорно-молібденово-вольфррамового реактиву $P$ і 10,0 мл води $P$ доводили розчином 290 г/л натрію карбонату $P$ до об'єму 25,0 мл. Через 30 хв вимірювали оптичну густину (2.2.25) розчину за довжини хвилі 760 нм $\left(\mathrm{A}_{3}\right)$, використовуючи як компенсаційний розчин воду $P$.

Вміст танінів $(X, \%)$ у перерахунку на пірогалол обчислювали за фрормулою:

$$
X=\frac{62,5 \cdot\left(A_{1}-A_{2}\right) \cdot m_{2}}{A_{3} \cdot m_{1}},
$$

де $m_{1}$ - маса випробовуваного зразка, г;

$m_{2}$ - маса пірогалолу, г [9].

РЕЗУЛЬТАТИ Й ОБГОВОРЕННЯ. РеЗУЛЬТаТИ визначення кількісного вмісту суми френольних сполук у артишоку суцвіттях, часнику листі та цибулинах наведено в таблиці.

Як видно з таблиці, вміст суми френольних сполук, визначений перманганатометричним методом, в артишоку суцвіттях становив 9,74 \%, у часнику листі - 8,96 \%, у часнику цибулинах 4,85 \%. При використанні спектрофотометричного методу в перерахунку на галову кислоту вміст суми френольних сполук в артишоку суцвіттях складав 6,58 \%, у часнику листі-6,22 \%, у часнику цибулинах - 2,87 \%. При визначенні вмісту суми фенольних сполук за методикою ДФУ було одержано такі результати: в артишоку суцвіттях - 4,43 \%, у часнику листі - 3,91 \%, у часнику цибулинах - 2,11 \%. Отримані результати свідчать про те, що вміст суми фенольних сполук найбільший при використанні перманганатометричного методу. Це можна пояснити сильними окисними властивостями титранту. Порівняльний аналіз вмісту суми фенольних сполук у сировині часнику показав, що в листі накопичується більше френольних сполук, ніж у цибулинах. Результати проведених досліджень дозволяють рекомендувати сировину, яку досліджували, як рослинні джерела фенольних сполук у складі лікарських субстанцій.

Таблиця - Результати визначення кількісного вмісту суми фенольних сполук у артишоку суцвіттях, часнику листі та цибулинах

\begin{tabular}{|l|c|c|c|}
\hline \multirow{2}{*}{ Об'єкт дослідження } & \multicolumn{3}{|c|}{ Кількісний вміст суми френольних сполук, \% } \\
\cline { 2 - 4 } & $\begin{array}{c}\text { перманганато- } \\
\text { метричний метод }\end{array}$ & $\begin{array}{c}\text { спектрофотометричний } \\
\text { метод (у перерахунку } \\
\text { на галову кислоту) }\end{array}$ & $\begin{array}{c}\text { спектрофотометричний } \\
\text { метод } \\
\text { (методика ДФу) }\end{array}$ \\
\hline Артишоку суцвіття & $9,74 \pm 0,21$ & $6,58 \pm 0,18$ & $4,43 \pm 0,14$ \\
\hline Часнику листя & $8,96 \pm 0,19$ & $6,22 \pm 0,16$ & $3,91 \pm 0,12$ \\
\hline Часнику цибулини & $4,85 \pm 0,19$ & $2,87 \pm 0,14$ & $2,11 \pm 0,12$ \\
\hline
\end{tabular}

ВИСНОВКИ. 1. Кількісний вміст суми феенольних сполук в артишоку суцвіттях, часнику листі тацибулинах визначали різними методами: перманганатометричним, спектросротометричним у перерахунку на галову кислоту, спектрофотометричним за методикою ДФу.

\section{СПИСОК ЛІТЕРАТУРИ}

1. Войцехівська О. В. Фенольні сполуки: різноманіття, біологічна активність, перспективи застосування / О. В. Войцехівська, О. В. Ситар, Н.Ю.Таран // Вісн. Харк. нац. аграр. ун-ту. Серія “Біологія". -2015. Вип. 1 (34). - С. 104-119.

2. Іващенко І. В. Дослідження фенольних сполук полину естрагенового (Artemisia dracunculus L.) за
2. У результаті проведеного експерименту було встановлено, що френольні сполуки більше накопичуються в артишоку суцвіттях і часнику листі, а в часнику цибулинах їх вміст нижчий.

3. Одержані результати дозволяють рекомендувати артишоку суцвіття, часнику листя та цибулини як рослинні джерела френольних сполук у складі лікарських субстанцій. 
4. Ковтун-Водяницька С. М. Сумарний вміст фенольних сполук у надземній частині інтродуцентів роду Isodon (Schrad. ex Benth.) / С. М. Ковтун-Водяницька, В. Ф. Левон // Наук. записки. Біологія та екологія. 2015. - 171. - C. 25-28.

5. Дослідження фенольних сполук хризантеми садової багаторічної (Chrysanthemum $\times$ hortorum Bailey) / С. М. Марчишин, О. Л. Демидяк, О. В. Полонець, М. С. Гарник // Мед. та клініч. хімія. -2016. -18, № 2 (67). - C. 48-53.

6. Государственная фрармакопея СССР: Общие методы анализа / МЗ СССР. - 11-е изд., дополн. - М. : Медицина, 1987. - 336 с.

\section{REFERENCES}

1. Voitsekhivska, O.V., Sytar, O.V., \& Taran, N.Iu. (2015). Fenolni spoluky: riznomanittia, biolohichna aktyvnist, perspektyvy zastosuvannia [Phenolic compounds: diversity, biological activity, prospects of application]. Visnyk Kharkivskoho natsionalnoho ahrarnoho universytetu. Seriia biolohiia - Journal of Kharkiv National Agrarian University. Series Biology, 1 (34), 104-119 [in Ukrainian].

2. Ivashchenko, I.V. (2016) Doslidzhennia fenolnykh spoluk polynu estrahenovoho (Artemisia dracunculus L.) za introduktsii v Zhytomyrskomu Polissi [Research of phenolic compounds of the estragenic worm (Artemisia dracunculus L.) after introduction in Zhytomyr Polissia]. Ahroekonomichnyi zhurnal - Agroeconomic Journal, 2, 60-64 [in Ukrainian].

3. Menshchikova, E.B., Lankin, V.Z., \& Kandalintseva, N.V. (2012). Fenolnye antioksidanty v biologii i meditsine. Stroenie, svoystva, mekhanizmy deystviya [Phenolic antioxidants in biology and medicine. Structure, properties, mechanisms of action]. LAP LAMBERT Academic Publishing [in Russian].

4. Kovtun-Vodianytska, S.M., \& Levon, V.F. (2015) Sumarnyi vmist fenolnykh spoluk u nadzemnii chastyni introdutsentiv rodu Isodon (Schrad. ex Benth.) [The total content of phenolic compounds in the above-ground part of the introducers of the genus Isodon (Schrad ex Benth.)] Naukovi zapysky. Biolohiia ta ekolohiia - Scientific Notes. Biology and Ecology, 171, 25-28 [in Ukrainian].

5. Marchyshyn, S.M., Demydiak, O.L., Polonets, O.V., \& Harnyk, M.S. (2016). Doslidzhennia fenolnykh spoluk
7. Кацуба І. К. Дослідження фенольних сполук листя мати-й-мачухи / І. К. Кацуба, В. С. Кисличенко, О. М. Новосел // Укр. мед. альм. - 2011. - 14, № 6 . C. $92-94$.

8. Мусієнко С. Г. Дослідження фенольних сполук сировини лавра благородного / С. Г. Мусієнко, В. С. Кисличенко // Зб. наук. праць співробітників НМАПО імені П. Л. Шупика. -2014. - Вип. 23 (4). - С. 341-344.

9. Державна Фармакопея України : в 3 т. / ДП "Український науковий фармакопейний центр якості лікарських засобів". - 2-ге вид. - Х. : ДП “Український науковий фрармакопейний центр якості лікарських засобів", 2015. - Т. 1. - 1130 с.

khryzantemy sadovoi bahatorichnoi (Chrysanthemum $\times$ hortorum Bailey) [Research of phenolic compounds by chrysanthemums of garden perennials (Chrysanthemum $\times$ hortorum Bailey)]. Medychna ta klinichna khimiia Medical and Clinical Chemistry, 18 (2), 48-53 [in Ukrainian].

6. Gosudarstvennaya farmakopeya SSSR: Obshchie metody analiza [State Pharmacopoeia of the USSR: General Methods of Analysis]. Moscow: Meditsina [in Russian].

7. Katsuba, I.K., Kyslychenko, V.S., \& Novosel, O.M. (2011). Doslidzhennia fenolnykh spoluk lystia maty-imachukhy [Research of phenolic compounds of motherand-stepmother leaves]. Ukrainskyi medychnyi almanakh - Ukrainian Medical Almanac, 14 (6), 92-94 [in Ukrainian].

8. Musiienko, S.H., \& Kyslychenko, V.S. (2014) Doslidzhennia fenolnykh spoluk syrovyny lavra blahorodnoho [Research of phenolic compounds of raw materials of the noble laurel]. Zbirnyk naukovykh prats spivrobitnykiv NMAPO imeni P. L. Shupyka - Collection of scientific works of NMAPE employees named after P.L. Shupyk, 23 (4), 341-344 [in Ukrainian].

9. Derzhavna Farmakopeia Ukrainy: v 3 t. / DP "Ukrainskyi naukovyi farmakopeinyi tsentr yakosti likarskykh zasobiv" [State Pharmacopoeia of Ukraine: in 3 vol. / State Enterprise "Ukrainian Scientific Pharmacopoeia Center of Quality of Medicines]. Kharkiv: "Ukrainskyi naukovyi farmakopeinyi tsentr yakosti likarskykh zasobiv" [in Ukrainian].

А. И. Федосов, В. С. Кисличенко, Е. Н. Новосел НАЦИОНАЛЬНЫЙ ФАРМАЦЕВТИЧЕСКИЙ УНИВЕРСИТЕТ, ХАРЬКОВ

\section{ОПРЕДЕЛЕНИЕ КОЛИЧЕСТВЕННОГО СОДЕРЖАНИЯ СУММЫ ФЕНОЛЬНЫХ СОЕДИНЕНИЙ В АРТИШОКА СОЦВЕТИЯХ, ЧЕСНОКА ЛИСТЬЯХ И ЛУКОВИЦАХ}

\section{Резюме}

Вступление. Фенольные соединения - наиболее распространенный класс биологически активных веществ растительного происхождения. Они проявляют антиоксидантное, противоопухолевое, антимутагенное, антиатеросклеротическое, антибактериальное, противовирусное, седативное, противо- 
язвенное и противовоспалительное действие. Значительное распространение френольных соединений в растительном мире и их применение в медицинской практике обуславливают актуальность определения их количественного содержания в перспективных видах растений, таких, как артишок посевной и чеснок посевной.

Цель исследования - определить количественное содержание суммы френольных соединений в артишока соцветиях, чеснока листьях и луковицах.

Методы исследования. Объектами исследования было выбрано артишока соцветия, чеснока листья и луковицы. Количественное содержание суммы френольных соединений в них определяли, используя разные методы: перманганатометрический, спектрофротометрический в пересчете на галловую кислоту, спектрофотометрический по методике ГФУ.

Результаты и обсуждение. Количественное содержание суммы френольных соединений, определенное перманганатометрическим методом, в артишока соцветиях составило 9,74 \%, в чеснока листьях 8,96 \%, в чеснока луковицах - 4,85 \%; содержание, определенное спектрофотометрическим методом в пересчете на галловую кислоту, в артишока соцветиях составило 6,58 \%, в чеснока листьях - 6,22 \%, в чеснока луковицах - 2,87 \%; содержание, определенное спектрофотометрическим методом по методике ГФУ, в артишока соцветиях составило 4,43 \%, в чеснока листьях - 3,91 \%, в чеснока луковицах - 2,11 \%.

Выводы. Количественное содержание суммы фенольных соединений в артишока соцветиях, чеснока листьях и луковицах определяли разными методами: перманганатометрическим, спектрофротометрическим в пересчете на галловую кислоту, спектрофротометрическим по методике ГФУ. В результате проведенного эксперимента было установлено, что френольные соединения больше накапливаются в артишока соцветиях и чеснока листьях, а в чеснока луковицах их содержание ниже. Полученные результаты позволяют рекомендовать артишока соцветия, чеснока листья и луковицы в качестве растительных источников френольных соединений в составе лекарственных субстанций.

КЛЮЧЕВЫЕ СЛОВА: артишок посевной; чеснок посевной; фенольные соединения; перманганатометрия; спектрофотометрия; количественное определение.

A. I. Fedosov, V. S. Kyslychenko, O. M. Novosel NATIONAL UNIVERSITY OF PHARMACY

\section{QUANTITATIVE CONTENT OF THE SUM OF PHENOLIC COMPOUNDS DETERMINATION IN ARTICHOKE INFLORESCENCES, GARLIC LEAVES AND BULBS}

\section{Summary}

Introduction. Phenolic compounds are the most abundant class of biologically active compounds of herbal origin. They possess antioxidant, anti-tumor, antimutagenic, antisclerotic, antibacterial, antiviral, sedative, anti-ulcer and anti-inflammatory activity. Wide distribution of phenolic compounds in the plant world and their usage in medical practice provide the importance of their quantitative determination in prospective plant species, such as artichoke and garlic.

The aim of the study - determination of quantitative content of phenolic compounds in artichoke inflorescences, garlic leaves and bulbs.

Research Methods. The content of phenolic compounds was determined using various methods: permanganatometric, spectrophotometric calculated on gallic acid, spectrophotometric according to the SPU method.

Results and Discussion. The content of the sum of phenolic compounds, determined by permanganatometry, comprised $9.74 \%$ in artichoke inflorescences, $8.96 \%$ in garlic leaves and $4.85 \%$ - in garlic bulbs; determined spectrophotometrically calculated on gallic acid in artichoke inflorescences was $6.58 \%$, in garlic leaves - 6.22 \%, in garlic bulbs - $2.87 \%$; determined spectrophotometrically according to the SPU method in artichoke inflorescences comprised $4.43 \%$, in garlic leaves $-3.91 \%$, and in garlic bulbs $-2.11 \%$.

Conclusions. The quantitative content of phenolic compounds in artichoke, garlic leaves and bulbs was determined using various methods: permanganatometric, spectrophotometric calculated on gallic acid, spectrophotometric according to the SPU method. As a result of the experiment, it was found that phenolic compounds accumulate in the artichoke inflorescences and garlic leaves, and in garlic bulbs their content is lower. The results obtained allow the recommending artichoke inflorescences, garlic leaves and bulbs as the herbal sources of phenolic compounds.

KEY WORDS: artichoke; garlic; phenolic compounds; permanganatometry; spectrophotometry; quantitative determination.

Адреса для листування: А. І. Федосов, Національний фармацевтичний університет, вул. Пушкінська, 53, Харків, 61002, Україна, e-mail: fedosov.a@ukr.net. 